\title{
Connecting the dots: a story of unknown fever, acute coronary syndrome and pan-aortitis—an occult relapse of a large vessel vasculitis
}

\author{
Abuelmagd Abdalla, ${ }^{\oplus 1}$ Imran Ali, ${ }^{1}$ David Murphy, ${ }^{2}$ Eamonn Molloy ${ }^{1}$
}

${ }^{1}$ Rheumatology Department, St. Vincent's University Hospital, Dublin, Ireland

${ }^{2}$ Radiology Department, St. Vincent's University Hospital, Dublin, Ireland

\section{Correspondence to} Dr Abuelmagd Abdalla, dr_abuelmagd@icloud.com

Accepted 18 April 2019

\section{DESCRIPTION}

A 76-year-old woman presented to our emergency department with acute chest pain. She has a history of giant cell arteritis (GCA) 2 years previously which was successfully treated and weaned off steroids 14 months later. On arrival, her physical examination was unremarkable with no suggestion of sepsis. She was found to have dynamic ECG changes and borderline positive troponin T. A provisional impression of unstable angina was outlined and scheduled for a coronary angiogram the following day, which showed minor atheroma without obstruction.

Her labs revealed elevated inflammatory markers and normochromic normocytic anaemia. Full septic screening and autoimmune profile were negative. She was noted to have night sweats and fever up to $39^{\circ} \mathrm{C}$ the following few days. The patient's chest pain did not improve and she continued to be febrile for the next week in the hospital with no cause revealed by subsequent investigations and infectious disease consultation.

At this point, a consult to rheumatology was made for an underlying unknown systemic illness. She admitted being relatively unwell for the recent 6 weeks with ongoing night sweats for the past 6 months but denied any specific GCA or Polymyalgia Rheumatica (PMR) symptoms. On review of medical history, her GCA diagnosis at the time was based on somehow a similar presentation of an unknown febrile systemic illness but accompanied by bilateral temporal headaches with a weakly palpable right temporal artery (TA). Her temporal biopsy showed no arterial tissue. However, as she was otherwise satisfying the American College of Rheumatology (ACR) 1990 GCA criteria, ${ }^{1}$ she

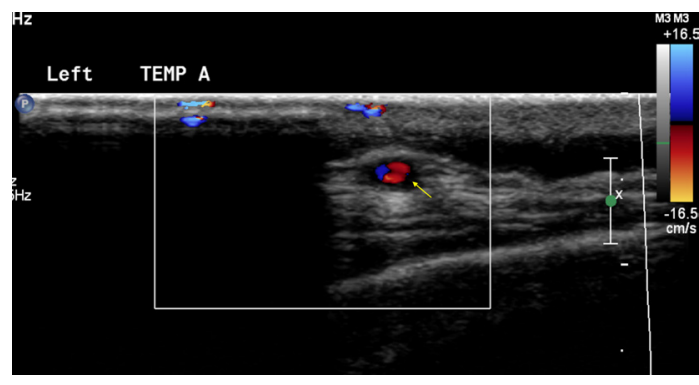

Figure 1 Colour Doppler ultrasound image shows circumferential hypoechoic wall oedema (arrowhead) of the superficial temporal artery, known as 'Halo' sign.

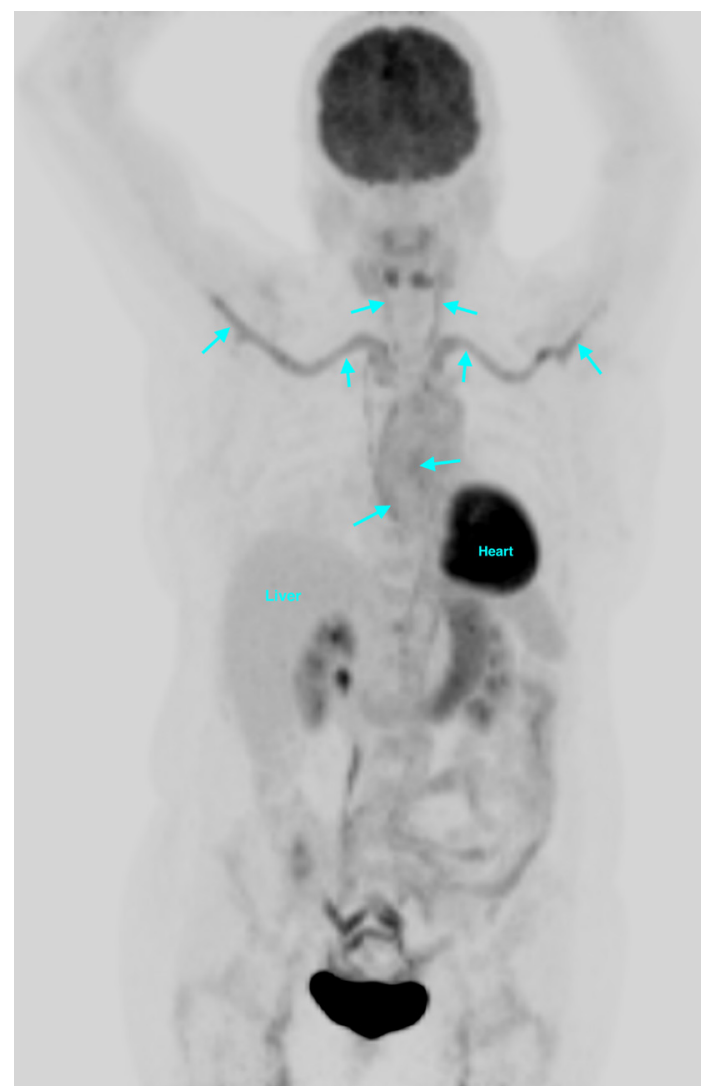

Figure 2 Coronal maximum intensity projection positron emission tomographic image showing the diffuse arterial uptake greater than background liver activity in the thoracic aorta, subclavian/axillary arteries and both proximal carotids (arrowheads).

was managed as such with good response and recovery.

This time, her TA ultrasound revealed a positive 'halo' sign (figure 1) on the left side suggesting a possibly active GCA. She then had CT angiogram of her aorta and major branches which showed diffuse thickening of the thoracic and abdominal aorta. Hybrid 18 F-fluorodeoxyglucose positron emission tomography/CT (FDG-PET/CT) scan revealed increased vascular FDG uptake throughout her thoracoabdominal aorta, bilateral subclavian, proximal carotids and axillary arteries (figures 2 and 3 ). The patient received $1 \mathrm{~g}$ of intravenous methylprednisolone for 3 days followed by oral prednisolone $60 \mathrm{mg} /$ day with a satisfactory response to symptoms, fever and inflammatory markers. Given the 


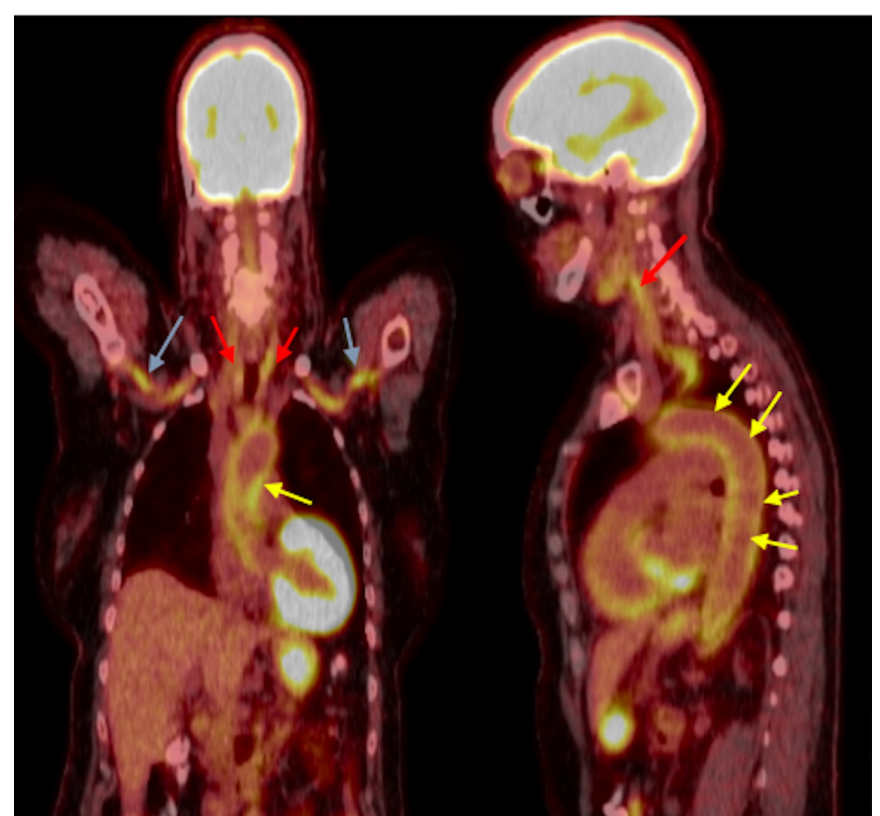

Figure 3 Coronal (left) and sagittal (right) fused fluorodeoxyglucose positron emission tomographic/CT images highlighting the diffuse increased vascular wall uptake of the ascending and descending thoracic aorta (yellow arrowheads), subclavian/axillary arteries (blue arrowheads) and proximal common carotid arteries (red arrowheads).

nature of this serious relapse, ustekinumab was added on 2 months later. At 6 months, she remained in remission and her prednisolone reduced to $5 \mathrm{mg} / \mathrm{day}$.

There is no single diagnostic test for GCA. The diagnosis is based on a combination of compatible clinical, laboratory and imaging findings with/without TAbiopsy. ACR 1990 GCA criteria do not include imaging. Although it remains the gold standard, the yield of TA biopsy for diagnosis is low. ${ }^{2}$ CT or magnetic resonance angiography is useful in delineating the vascular wall abnormalities, but they do not indicate disease activity, as does FDG-PET/CT. ${ }^{3}$ The latter is also useful in multiterritorial or occult disease. ${ }^{4}$ In a recent meta-analysis, hypoechoic halo on TA ultrasound is shown to have better sensitivity than biopsy, ${ }^{5}$ and when used concomitantly, it can add significantly to the diagnostic yield. ${ }^{6}$ This case highlights the dilemma of arriving at GCA diagnosis in practice, often by combining all the above tests.

\section{Learning points}

- Giant cell arteritis (GCA) is the commonest vasculitis in the elderly population with serious vascular morbidities including aneurysms, irreversible sight loss and strokes. Therefore, it should be considered in the differential of an occult systemic illness or unknown fever.

- Fluorodeoxyglucose positron emission tomography/CT has a pivotal role in revealing disease activity in atypical cases or multivascular territory involvement.

- GCA is a challenging diagnosis in many numbers of cases with a high rate of variability in all the tests used and can strongly depend on the local access and expertise.

Acknowledgements 'Connecting the dots' was inspired by Steve Jobs' renowned commencement address at Stanford University 2005. 'You cannot connect the dots looking forward, you can only connect them looking backward'. https://youtu.be/ UF8UR6Z6KLC

Contributors AA and IA are the Registrars directly involved in patient care, EM is the attending rheumatologist and DM is the reporting radiologist.

Funding The authors have not declared a specific grant for this research from any funding agency in the public, commercial or not-for-profit sectors.

Competing interests None declared.

Patient consent for publication Obtained.

Provenance and peer review Not commissioned; externally peer reviewed.

\section{REFERENCES}

1 Hunder GG, Bloch DA, Michel BA, et al. The American College of Rheumatology 1990 criteria for the classification of giant cell arteritis. Arthritis \& Rheumatism 2010;33:1122-8.

2 Cristaudo AT, Mizumoto R, Hendahewa R. The impact of temporal artery biopsy on surgical practice. Ann Med Surg 2016;11:47-51.

3. Slart R. Writing group, Reviewer group, Members of EANM Cardiovascular, Members of EANM Infection \& Inflammation, Members of Committees, SNMMI Cardiovascular, Members of Council, PET Interest Group, Members of ASNC, EANM Committee Coordinator. FDG-PET/CT(A) imaging in large vessel vasculitis and polymyalgia rheumatica: joint procedural recommendation of the EANM, SNMMI, and the PET Interest Group (PIG), and endorsed by the ASNC. Eur J Nucl Med Mol Imaging 2018;45:1250-69.

4 Hay B, Mariano-Goulart D, Bourdon A, et al. Diagnostic performance of 18F-FDG PET-CT for large vessel involvement assessment in patients with suspected giant cell arteritis and negative temporal artery biopsy. Ann Nucl Med 2019.

5 Rinagel M, Chatelus E, Jousse-Joulin S, et al. Diagnostic performance of temporal artery ultrasound for the diagnosis of giant cell arteritis: a systematic review and metaanalysis of the literature. Autoimmun Rev 2019;18:56-61.

6 Conway R, O'Neill L, McCarthy GM, et al. Performance characteristics and predictors of temporal artery ultrasound for the diagnosis of giant cell arteritis in routine clinical practice in a prospective cohort. Clin Exp Rheumatol 2019.

Copyright 2019 BMJ Publishing Group. All rights reserved. For permission to reuse any of this content visit

https://www.bmj.com/company/products-services/rights-and-licensing/permissions/

BMJ Case Report Fellows may re-use this article for personal use and teaching without any further permission.

Become a Fellow of BMJ Case Reports today and you can:

- Submit as many cases as you like

- Enjoy fast sympathetic peer review and rapid publication of accepted articles

- Access all the published articles

- Re-use any of the published material for personal use and teaching without further permission

For information on Institutional Fellowships contact consortiasales@bmjgroup.com

Visit casereports.bmj.com for more articles like this and to become a Fellow 